\title{
Trophic importance of Laminaria hyperborea to kelp forest consumers and the importance of bacterial degradation to food quality
}

\author{
K. M. Norderhaug ${ }^{1, *}$, S. Fredriksen ${ }^{1}$, K. Nygaard ${ }^{2}$ \\ ${ }^{1}$ Department of Biology, University of Oslo, PO Box 1069, 0316 Oslo, Norway \\ ${ }^{2}$ Norwegian Institute for Water Research, PO Box 173 Kjelsås, 0411 Oslo, Norway
}

\begin{abstract}
The nutritional value of kelp Laminaria hyperborea (Gunn.) Foslie and the importance of bacterial degradation in making kelp available to consumers were tested by no-choice feeding experiments. Fresh and dead kelp material degraded in situ was sampled. In the laboratory, fresh kelp was degraded for 3,14 and $44 \mathrm{~d}$ by kelp associated bacterial communities under aerobic and anaerobic conditions. The fresh and degraded kelp products were fed to the kelp associated amphipods Jassa falcata, Lembos websteri, Ampithoe rubricata and Gammarus locusta and the gastropod Rissoa parva. None of the amphipods tested could survive or grow on fresh kelp, but bacterial degradation decreased the $\mathrm{C}: \mathrm{N}$ ratio and the phlorotannin content and made kelp available as food. In contrast, the gastropod survived on both fresh and degraded kelp. ${ }^{13} \mathrm{C}^{12} \mathrm{C}$ and ${ }^{15} \mathrm{~N}:{ }^{14} \mathrm{~N}$ isotope analysis of fauna and possible food items sampled in the field suggested that kelp derived particulate organic matter (POM) is an important food source for kelp epifauna.
\end{abstract}

KEY WORDS: Kelp forest - Amphipods · Gastropods · Bacterial degradation · Feeding experiments · Food quality Resale or republication not permitted without written consent of the publisher

\section{INTRODUCTION}

Several papers in recent years have addressed the relationships between the fitness of macroinvertebrates associated with macroalgae and the quality of their food. The feeding habits of these animals include herbivory, detritivory and omnivory (Lawrence 1975, Nicotri 1977, Nair \& Anger 1979b, Mann 1982b, Hagen 1983, Shillaker \& Moore 1987, Hay et al. 1988, Duggins \& Eckman 1997, Cruz-Rivera \& Hay 2000b, 2001, Toth \& Pavia 2002a,b). Laboratory experiments have shown how diets of different quality, consisting of red, green and brown algae, affect consumer fitness (Costa et al. 1996, Cruz-Rivera \& Hay 2000a,b, Hemmi \& Jormalainen 2002) and how consumer fitness may increase on mixed diets including additions of animal matter (Costa et al. 1996, CruzRivera \& Hay 2000a,b). Such experiments represent idealised situations in which growth can be maximised by optimising diets and supplies, a situation that may not be a common situation in nature.

In NE Atlantic coastal waters, Laminaria hyperborea (Gunn.) Foslie forms extensive forests (Kain 1967). The kelp functions as a habitat that supports a diverse and numerous epifauna dominated by gastropods and amphipods (Moore 1972b, 1973, Schultze et al. 1990, Christie 1995). In addition, kelp primary production is a potentially important food source for these consumers. On the Norwegian coast the greatest standing stocks are 30 to $40 \mathrm{~kg} \mathrm{~m}^{-2}$ wet weight, and the yearly primary production is large (Sjøtun et al. 1995). Thus, any consumer able to exploit the kelp production will benefit from its ready availability.

Although grazing by sea urchins (Lawrence 1975, Mann 1982b, Hagen 1983) and a few gastropods (Fretter \& Manly 1977, Toth \& Pavia 2002a,b) are important exceptions, most of the standing stock in temperate kelp beds is not grazed, but released as 
particulate organic matter, POM (Mann 1982, Hay \& Steinberg 1992). Several factors that prevent animals from eating various algae have been reported. These include rigidness (Steneck \& Watling 1982, Padilla 1985, Taylor et al. 2002) and the production of deterrent secondary metabolites (Duggins \& Eckman 1997, Poore \& Steinberg 1999, Granado \& Caballero 2001, Taylor et al. 2002). These characteristics are also found in Laminaria hyperborea (Toth \& Pavia 2002a,b). In addition, kelp tissue $\mathrm{C}: \mathrm{N}$ exceeds that of animal tissue. If the $\mathrm{C}: \mathrm{N}$ of animal tissue is constant, then the $\mathrm{N}$ limitation could limit $C$ utilisation by the animal (Hessen 1992, Hessen \& Sterner 1994), which must then compensate for the low food quality with an increased feeding rate (Cruz-Rivera \& Hay 2000b). There may be a critical $\mathrm{C}: \mathrm{N}$ ratio above which the algae can no longer support the growth of the consumer (cf. Hessen \& Bjerkeng 1997). Russel-Hunter (1970) calculated that most animals require a $\mathrm{C}: \mathrm{N}$ ratio below 17 in their diet. The kelp C:N ratio is higher than this for most of the year (Sjøtun et al. 1996), and it may therefore be unsuitable as food for at least some parts of the year.

Bacterial degradation of eroded kelp fragments may make primary production available to consumers (Newell et al. 1982, Newell \& Field 1983, Seiderer \& Newell 1985, Duggins et al. 1989). Studies on Laminaria digitata (Huds.) Lamouroux have shown increased microbial activity on old parts of the laminae (Corre et al. 1989a,b). At least some of the eroded POM is transported onshore or into deeper waters (Thrush 1986, Vetter 1995, Bustamente \& Branch 1996), but a lot of POM is expected to sediment within the kelp forest system. Dense bacterial communities on kelp surfaces (Armstrong et al. 2000) may degrade released POM and increase its nutritional value by reducing the $\mathrm{C}: \mathrm{N}$ ratio and the content of phlorotannins. Such 'ageing' may make algae more suitable as invertebrate food (Duggins \& Eckman 1997, Pennings et al. 2000). The bacterial community itself may also represent an important contribution to the diet (Cummins 1974, Newell et al. 1982, Newell \& Field 1983). Alternatively, primary production may be lost to the fauna through bacterial respiration. Kelp degradation is usually expected to be aerobic because kelp forests are found in exposed sites (Kain 1967). However, kelp accumulations on the sea floor may undergo anaerobic degradation (Thrush 1986).

Kelp-associated animals may have dietary requirements reflecting different activity levels and habitat adaptations. They are mainly associated with epiphytic algae on the kelp stipes and in the holdfasts (hapteron), and it is possible to discriminate between epiphyte- and holdfast-associated fauna according to their habitat preferences (Norderhaug et al. 2002). A more vigorous environment on the epiphytes than in the holdfasts may require more mobile species on the epiphytes, but a different distribution of food generalists and specialists between epiphytes and holdfasts may also be expected. The holdfasts function as sediment traps (Moore 1972a, Conradi et al. 1997), and are therefore expected to accumulate smaller and more degraded detritus particles than the epiphytes. The fauna living on epiphytes are more mobile than the holdfast fauna (Norderhaug et al. 2002). This may reflect their need to find food rapidly when it is in short supply and a need to exploit any available food sources, even those of low quality. Fauna on epiphytes may have mixed diets, while the holdfast fauna may be more discriminating. On the other hand, the more mobile epiphyte-associated fauna may require a higher food quality than the more sedentary holdfast species (cf. Cruz-Rivera \& Hay 2000a, 2001).

This study tested the hypotheses that POM from kelp can serve as food for kelp associated macrofauna and that bacterial degradation is important in increasing the quality of POM. To test the hypotheses, selected macrofaunal species were fed fresh and degraded kelp in no-choice feeding experiments in the laboratory. Survival and growth were monitored. Isotope data $\left({ }^{15} \mathrm{~N}:{ }^{14} \mathrm{~N}\right.$ and $\left.{ }^{13} \mathrm{C}:{ }^{12} \mathrm{C}\right)$ were obtained for the same animal species and potential food items were sampled in the field to determine food (carbon) sources and the trophic position of the animals in situ (Rau et al. 1983, 1989, Dunton 2001).

\section{MATERIALS AND METHODS}

Field sampling. Laminaria hyperborea lamina tissue and macro-invertebrates for laboratory experiments were sampled in the archipelago of Møre og Romsdal county (Finnøy, 62 $50^{\prime} \mathrm{N}$ ) in Norway. Here, the standing stock of L. hyperborea is $16.3( \pm 3.6) \mathrm{kg}$ $\mathrm{m}^{-2}$ (wet weight, own data) and the associated faunal communities are well developed (Norderhaug et al. 2002). Kelp laminae were sampled by SCUBA at $5 \mathrm{~m}$ depth. Also, dead and decomposed kelp was sampled nearby in a back eddy where kelp accumulates at $10 \mathrm{~m}$ depth (hereafter called in situ degraded kelp). Discs of lamina tissue of fresh and decomposed kelp were cut off with a knife and dried at $60^{\circ} \mathrm{C}$ for $72 \mathrm{~h}$ for later feeding experiments. Samples were taken in August (2000) when kelp C:N is high (Sjøtun et al. 1996). The bacterial community of lamina surfaces was isolated, cultivated in the laboratory, and stored at $5^{\circ} \mathrm{C}$ for later decomposition of kelp in the laboratory.

We carefully sampled 4 common amphipod and 1 gastropod species alive, and transported them to the 
laboratory, where they were kept at 12 to $14^{\circ} \mathrm{C}$ in a closed-circuit 15001 aquarium system. They were chosen to represent common kelp forest invertebrate families (Rissoidae, Ischyroceridae, Aoridae, Ampithoidae and Gammaridae). One of the dominant gastropods in kelp forests is the small thick-shelled Rissoa parva (da Costa) (Schultze et al. 1990, Christie 1995); it feeds on algae surfaces (Mann 1982a, Warén 1996). Jassa falcata (Montagu) is numerically the dominant kelp forest amphipod, and is associated with kelp epiphytes (Norderhaug et al. 2002), whereas Lembos websteri (Bate), a typical holdfast-associated species, is rather sedentary. Both are reported to be omnivorous (Nair \& Anger 1979b, Shillaker \& Moore 1987). Ampithoe rubricata (Montagu) is a large epiphyte-associated amphipod; no data are available on its feeding biology, but related species are herbivorous or omnivorous (Nicotri 1977, Cruz-Rivera \& Hay 2000a,b, 2001). Although most numerous in the tidal zone, Gammarus locusta (Linnaeus) is also common in the kelp forest. It is omnivorous, with a diverse diet including algae, deposit-feeding, and other animals (Costa \& Costa 1999) and it is even cannibalistic (Authors' pers. obs.).

For ${ }^{13} \mathrm{C}:{ }^{12} \mathrm{C}$, and ${ }^{15} \mathrm{~N}:{ }^{14} \mathrm{~N}$ isotope analysis, we sampled 106 to 110 individuals each of the macroinvertebrate species listed above, kelp laminae, the common epiphytic red algae Palmaria palmata (Linnaeus) Kuntze, Rhodomela confervoides (Hudson) Silva, Callophyllis laciniata (Hudson) Kützing, Delesseria sanguinea (Hudson) Lamouroux, Ptilota gunneri Silva, Membranoptera alata (Hudson) Stackhouse and Phycodrys rubens (Linnaeus) Batters, phytoplankton and POM. POM was sampled in sediment traps placed in a dense kelp forest (height $25 \mathrm{~cm}$, diameter $5 \mathrm{~cm}$ ) at $5 \mathrm{~m}$ depth from August to October (2000) at 2 sites. Phytoplankton was sampled by towing a plankton net (mesh size $20 \mu \mathrm{m}$ ) through the surface waters offshore. Samples were filtered through pre-combusted GF/C filters and frozen. Entire filters were ground to a powder prior to analysis. The macroinvertebrates were frozen.

Experimental degradation of kelp. Fresh-collected, dried kelp was crushed in liquid nitrogen to a powder consisting of particles covering a broad size range to meet species-specific differences in food particle-size preferences (Shillaker \& Moore 1987). We incubated $15 \mathrm{~g}$ of kelp powder in $200 \mathrm{ml} \mathrm{C}$-free but $\mathrm{N}$ - and P-rich

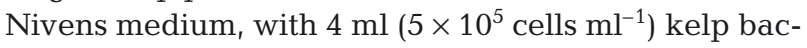
teria culture at $12^{\circ} \mathrm{C}$, in darkness, and under aerobic conditions (aerated) for 3, 14, or $44 \mathrm{~d}$. For the same number of days, $6 \mathrm{~g}$ of kelp powder were incubated in $50 \mathrm{ml}$ medium and $0.8 \mathrm{ml}$ kelp bacteria culture in closed, unaerated bottles and degraded anaerobically. The degraded kelp samples were dried $\left(60^{\circ} \mathrm{C}\right.$ for $\left.72 \mathrm{~h}\right)$ for later feeding experiments.
Feeding experiments. Juvenile Ampithoe rubricata and Gammarus locusta were used in short-period growth experiments terminated after $15 \mathrm{~d}$. In Jassa falcata (females only since male survival was lower) and Lembos websteri (both sexes, with no differences between females and males detected) adult survival only was monitored because there were too few juveniles. All animals were starved $24 \mathrm{~h}$ in advance and placed individually in $20 \mathrm{ml}$ wells on culture plates with food in excess. They were fed fresh kelp, in situ degraded kelp, and kelp experimentally degraded in aerobic and anaerobic conditions for 3, 14 and $44 \mathrm{~d}$. We used 2 control treatments. One provided no food and the other provided Tetra min ${ }^{\mathrm{TM}}$, (a highly nutritional commercial fish food consisting of crustaceans, fishes and algae) with added spinach. Each treatment used $60 \mathrm{~J}$. falcata, $50 \mathrm{~L}$. websteri and 30 specimens each of juvenile $A$. rubricata and G. locusta. The survival experiments were terminated when all control individuals in the no-food control treatment were dead. To avoid possible effects of drying, kelp that was frozen only and then degraded as described above were fed to juvenile G. locusta: 10 individuals in each treatment were given fresh frozen kelp and frozen kelp that had been degraded for 3 and $44 \mathrm{~d}$. No difference was detected between the to preservation methods by a 2-way ANOVA test with preservation method $(\mathrm{df}=1, \mathrm{MS}=$ 1.0, $F=1.1$ and $\mathrm{p}=0.36$ ) and degradation as factors.

In the case of Rissoa parva, 10 individuals were placed in each of 10 small bowls with discs of fresh kelp in excess. Individuals given no food served as controls. Gastropods feed by rasping algal surfaces (Hickman et al. 1993, Warén 1996), and R. parva was therefore only given food that could be served as discs (approximately $1 \times 1 \mathrm{~cm}$ in size), i.e. fresh kelp and in situ degraded kelp, but not experimentally degraded kelp (particles). In all experiments, water and food were changed and survival was monitored daily or every other day.

In the amphipod growth experiments, each individual was anaesthetized on the first and every fifth day (by low concentrations of ethyl carbamate, $\mathrm{C}_{3} \mathrm{H}_{7} \mathrm{NO}_{2}$ in seawater) and photographed before being quickly returned to its culture plate. Individual length (rostrum to telson) was monitored using Scion Image (www. scioncorp.com), and individual growth was calculated. When photographed, some amphipods lay in a more curved manner than others. This influenced the overlap of the body segments and thus the measured length. To compensate for this error, straight lines rather than a curved line were drawn from the rostrum to the telson. In this way the length were corrected for the most strongly curved individuals whose length would otherwise have been overestimated.

At the end of the experiments, all animals were dried $\left(72 \mathrm{~h}, 60^{\circ} \mathrm{C}\right)$ and crushed with a piston prior to $\mathrm{C}: \mathrm{N}$ 
analysis to determine to what extent the different species were able to regulate their tissue C:N content according to their food. Gastropod shells were removed prior to analysis using $1 \mathrm{M} \mathrm{HCl}$.

Phlorotannin assays and $\mathbf{C}: \mathbf{N}$ analysis. The phlorotannin content of kelp was analysed according to the method of Van Alstyne (1995) with some modifications (Dr. M. Abdullah pers. comm.). Phlorotannins were extracted in $9 \mathrm{ml}$ water with $1 \mathrm{ml}$ of $1 \mathrm{M}$ pyrophosphate from finely crushed algal material. The slurry was repeatedly stirred and allowed to react for $72 \mathrm{~h}$ at room temperature. Folin-Ciocalteau assays were performed to quantify the phlorotannin content in the extracts, using phloroglucinol (Sigma P 3502) as a standard (Van Alstyne 1995). The absorbance of the solutions was measured at $765 \mathrm{~nm}$.

The C:N content of 3 replicate 0.5 to $1.5 \mathrm{mg}$ samples of each kelp and animal sample was analysed using a Carlo Erba Elemental analyser (Model 1106).

${ }^{13} \mathrm{C}:{ }^{12} \mathrm{C}$ and ${ }^{15} \mathrm{~N}:{ }^{14} \mathrm{~N}$ isotope analysis. Prepared samples (3 to 10 replicates of 1 to $2 \mathrm{mg}$ each) of kelp, red algae, phytoplankton, invertebrates and POM from sediment traps were combusted in sealed tin capsules in an elemental analyser (Carlo Erba NA 1500). The combustion products $\mathrm{CO}_{2}, \mathrm{~N}_{2}$ and $\mathrm{H}_{2} \mathrm{O}$, were separated in cryogenic traps, leaving pure $\mathrm{CO}_{2}$ and $\mathrm{N}_{2}$ to be analysed on-line in a mass spectrometer. The results are expressed in standard $\delta$-notation $\left({ }^{13} \mathrm{C}:{ }^{12} \mathrm{C}\right.$ or $\left.{ }^{15} \mathrm{~N}:{ }^{14} \mathrm{~N}\right)$ relative to $\mathrm{PDB}$ and atmospheric air respectively:

$$
\delta X=\left\{\left(R_{\text {sample }} / R_{\text {standard }}\right)-1\right\} \times 1000
$$

where $X$ is $\mathrm{C}$ or $\mathrm{N}$ and $R$ is the ratio of the heavy to the light isotope.

Statistical analysis. Differences in amphipod survival of each species on the different treatments were tested by log-rank tests. In the Rissoa parva survival experiment, each bowl of 10 individuals was treated as 1 replicate and an ANOVA test on slopes (survival) was performed, followed by a multiple comparison according to the Tukey method.

In the growth experiments, amphipods were monitored individually, and each individual was treated as a replicate. To avoid violating the assumption of independent measurements resulting from repeated measures of the same individual, the slopes of the growth curve were calculated for each individual and used in ANOVA tests.

In ANOVA tests of growth (slopes), species (Gammarus locusta and Ampithoe rubricata) and treatment (animals fed kelp degraded in situ and experimentally [aerobically and anaerobically] for 3, 14 and $44 \mathrm{~d}$, and Tetra $\min ^{\mathrm{TM}}+$ spinach) were used as factors. The tests were probably slightly conservative because the experiment-induced mortality was expected to affect the weakest, slowest growing individuals most severely and kill more slow-growing individuals in the lowquality food treatments than in the high-quality treatments. All tests were performed with the S-PLUS (6.0) computer package.

\section{RESULTS}

Significant differences in the survival of the gastropod Rissoa parva between treatments were found (ANOVA, $2 \mathrm{df}, \mathrm{MS}=0.02, F=26.1, \mathrm{p}=4.9 \times 10^{-7}$ ). The gastropod survived better on fresh kelp than on no food (Tukey's test, estimate $=-0.07$, lower bound $=$ -0.10 , upper bound $=-0.04$, Fig. 1 ) and there was no significant difference in survival between gastropods fed on fresh or in situ degraded kelp (estimate $=0.001$, lower bound $=0.011$, upper bound $=-0.026$ ). The gastropod also survived longer without food than any amphipod.

There were significant differences in the survival of all amphipods between treatments (diets) (Fig. 2), but in contrast to the gastropod, fresh kelp had no positive effect on survival of the amphipods used in the experiments. According to log-rank tests, survival was even lower for Jassa falcata $\left(\chi^{2}=24.2,1 \mathrm{df}, \mathrm{p}=8.8 \times 10^{-7}\right)$ and Gammarus locusta $\left(\chi^{2}=12.5,1 \mathrm{df}, \mathrm{p}=4.2 \times 10^{-4}\right)$ fed fresh kelp than for control individuals given no food, but for Lembos websteri $\left(\chi^{2}=2.6,1 \mathrm{df}, \mathrm{p}=0.10\right)$ and Ampithoe rubricata $\left(\chi^{2}=0.5,1 \mathrm{df}, \mathrm{p}=0.49\right)$ there was no difference in survival between the 2 treatments. More amphipods survived on aerobically degraded kelp than on fresh kelp (Fig. 2), and log-rank tests confirmed that survival increased with increasing aerobic degradation for J. falcata: $\left(\chi^{2}=26.1, \mathrm{df}=2, \mathrm{p}=2.2 \times 10^{-7}\right)$ and $G$. locusta $\left(\chi^{2}=12.5, \mathrm{df}=2, \mathrm{p}=4.2 \times 10^{-4}\right)$. There was, however, only weak evidence for such a relationship for $A$. rubricata $\left(\chi^{2}=2.8, \mathrm{df}=1, \mathrm{p}=0.09\right)$ and L. websteri $\left(\chi^{2}=\right.$ $5.4, \mathrm{df}=2, \mathrm{p}=0.07$ ). They both survived well on kelp degraded for the short period ( $3 \mathrm{~d}$ ) and kelp degraded for

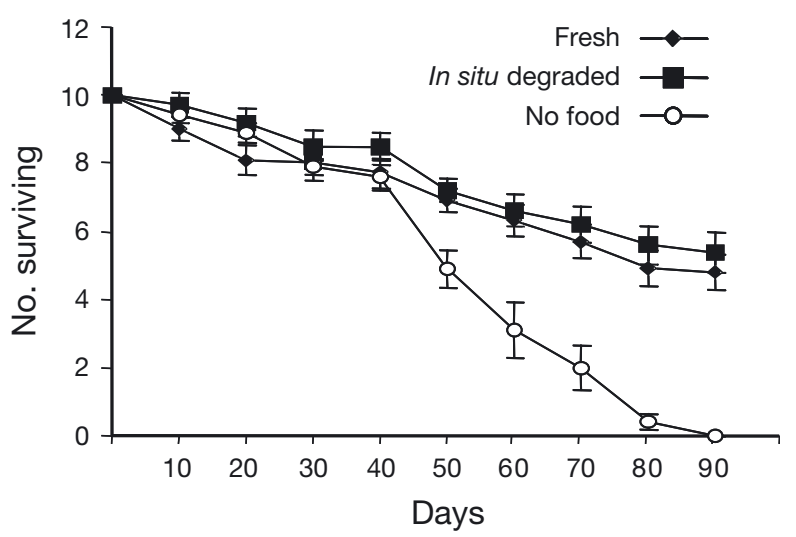

Fig. 1. Rissoa parva. Average $( \pm \mathrm{SE})$ survival (10 replicates each of 10 individuals) fed fresh and in situ degraded kelp. No food: controls 

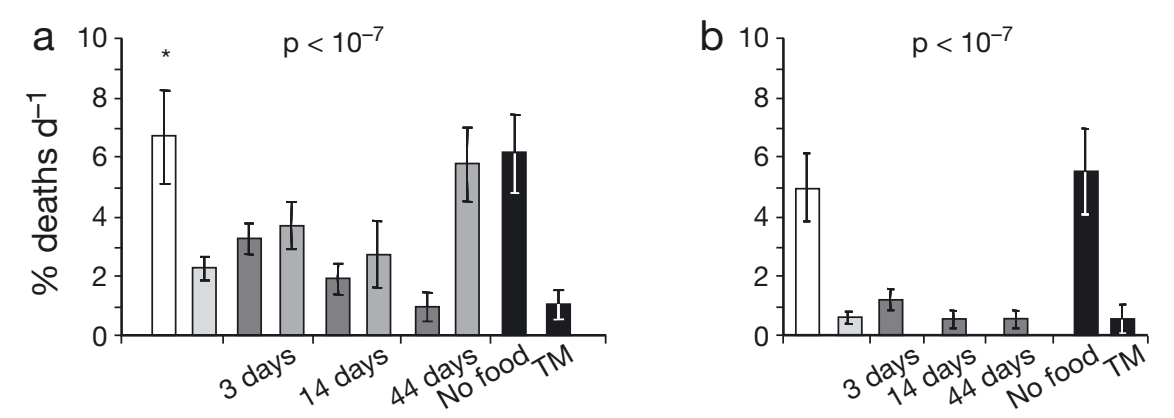

Fig. 2. (a) Jassa falcata, (b) Lembos websteri, (c) Ampithoe rubricata and (d) Gammarus locusta. Average $( \pm \mathrm{SE})$ death rates. Also shown are p values of log-rank tests on differences in survival: (a) $\chi^{2}=391,9 \mathrm{df}_{\text {; }}$ (b) $\chi^{2}=358,6 \mathrm{df}_{;}$(c) $\chi^{2}=$ $88,5 \mathrm{df}_{\text {; }}$ (d) $\chi^{2}=218,9 \mathrm{df}$. Amphipods were fed fresh, dried and degraded kelp; controls were either not fed, or were fed a commercial fish food, Tetra $\min ^{\mathrm{TM}}$. * No individuals survived to last day of experiment
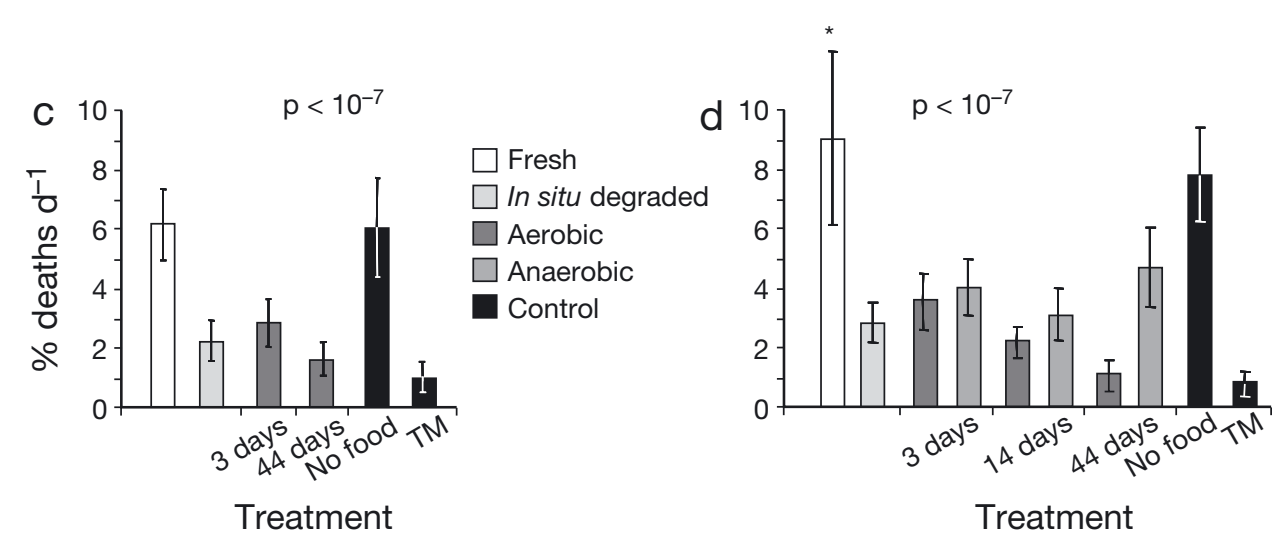

the longest period (44 d). In the treatments using kelp that had been aerobically degraded for the longest period (44 d), survival was almost the same as in the treatments using the highly nutritional Tetra $\min ^{\mathrm{TM}}+$ spinach treatment. Survival was generally lower on anaerobically degraded than on aerobically degraded kelp.

There was significant differences in growth between treatments (diets) for both Gammarus locusta and Ampithoe rubricata (Table 1). No significant differences were found between the 2 species. Growth paralleled survival and was higher for individuals given aerobically degraded kelp and in situ degraded kelp than for those given fresh kelp (Fig. 3). Growth

Table 1. Gammarus locusta and Ampithoe rubricata. Twoway ANOVA testing differences between growth of 2 amphipod species fed kelp degraded in situ or aerobically degraded experimentally for 3,14 or $44 \mathrm{~d}$, or fed with Tetra $\min ^{\mathrm{TM}}+$ spinach. Only individuals surviving to the last day of the experiment were included in the analysis (individuals given no food or fed on fresh kelp were therefore not included). Residuals $=$ df 177; $\mathrm{MS}=0.62$

\begin{tabular}{|lcccc|}
\hline & df & MS & $F$ & $p$ \\
\hline Species (S) & 1 & 0.13 & 0.21 & 0.64 \\
Treatment (T) & 4 & 14.7 & 23.7 & $<10^{-8}$ \\
$\mathrm{~S} \times \mathrm{T}$ & 3 & 0.14 & 0.24 & 0.86 \\
\hline
\end{tabular}

Fig. 3. (a) Ampithoe rubricata; (b) Gammarus locusta. Average $( \pm \mathrm{SE})$ growth of juveniles fed fresh and degraded kelp. Anaerobically degraded kelp was fed to G. locusta only. *Only 1 A. rubricata survived on fresh kelp for $15 \mathrm{~d}_{i}{ }^{* *}$ no individual survived for $15 \mathrm{~d}$, data therefore show growth until death
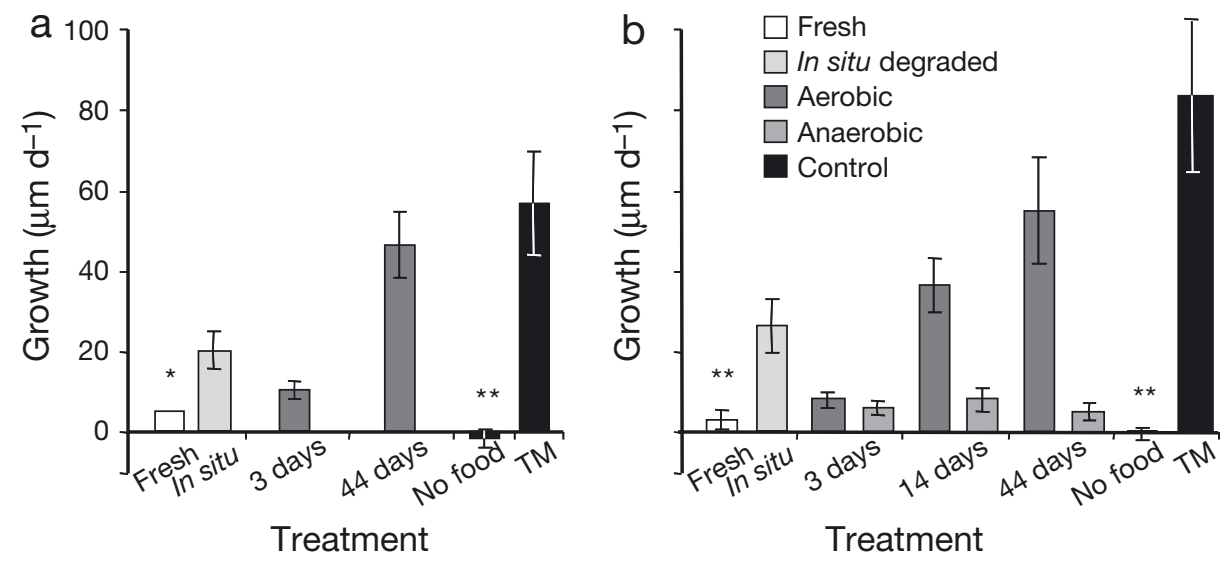

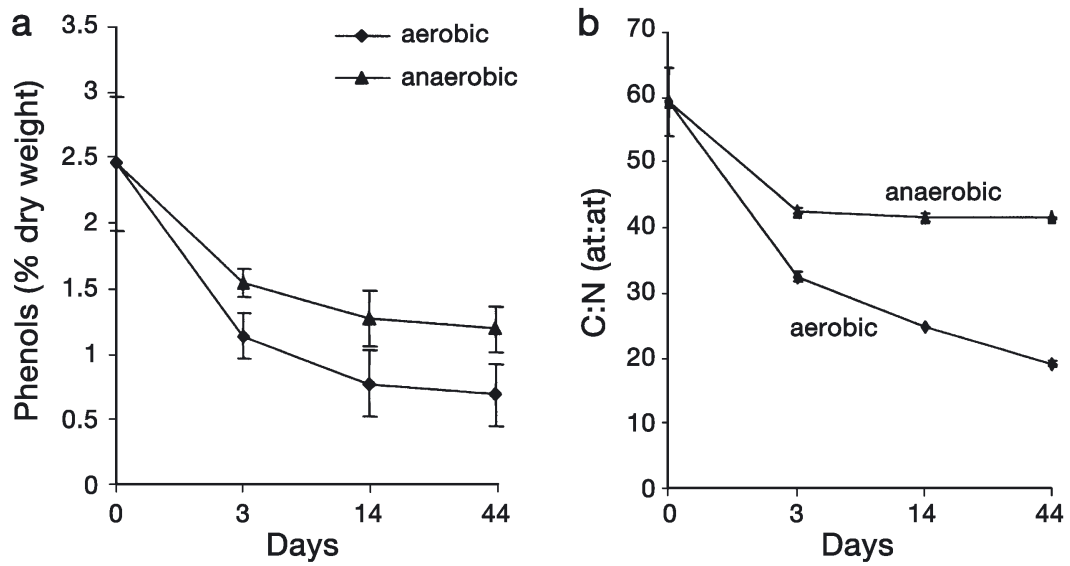

Fig. 4. Laminaria hyperborea. (a) Total phlorotannins content in fresh kelp $(0 \mathrm{~d})$, and kelp experimentally degraded (aerobically and anaerobically for 3 , 14 and $44 \mathrm{~d}) ;($ b) average $( \pm \mathrm{SE}) \mathrm{C}: \mathrm{N}$ at:at ratio of kelp degraded aerobically and anaerobically for 0 (fresh), 3, 14 and $44 \mathrm{~d}$

was higher on kelp degraded aerobically for longer periods. Growth on anaerobically degraded treatments was low and differed little (Fig. $3, \mathrm{df}=2, \mathrm{MS}=0.25, F=$ $0.37, \mathrm{p}=0.68$ in a global test on differences between any 3 anaerobic treatments for $G$. locusta) and was significantly lower than growth on the aerobic treatments $\left(\mathrm{df}=1, \mathrm{MS}=9.3, F=13.4, \mathrm{p}=4.2 \times 10^{-4}\right)$.

The content of phlorotannins in kelp decreased in parallel with increasing degradation in the laboratory, probably through leakage or bacterial degradation. It was almost $2.5 \%$ (dry weight) in fresh kelp and decreased to less than $1 \%$ in kelp experimentally degraded for $44 \mathrm{~d}$ (Fig. 4a). The decrease was larger and more rapid during aerobic degradation than during anaerobic degradation. The phlorotannin content of in situ degraded kelp was $0.89( \pm 0.36) \%$.

Likewise, the C:N (at:at) ratio of the combined mass of kelp and bacteria decreased rapidly with increasing degradation (Fig. 4b). After only $3 \mathrm{~d}$ of aerobic degradation, the C:N ratio had dropped from almost 60 in fresh kelp to nearly 30. After this initial drop, C:N decreased more slowly, reaching $<20$ after $44 \mathrm{~d}$. The ratio in the in situ degraded kelp was 24.2 $( \pm 5.2)$.

The C:N of the anaerobically degraded kelp decreased similarly, but degradation was slower and the ratio did not drop further than approx. 40. Even after $44 \mathrm{~d}$, no trace of sulphur was detected in any of the samples.

Amphipod tissue C:N was stable (approx. 5, Fig. 5), indicating that the experimental individuals could not regulate their tissue $\mathrm{C}: \mathrm{N}$ according to food quality. However, the $\mathrm{C}: \mathrm{N}$ ratio in tissue from the gastropod Rissoa parva was higher than in amphipod tissue and differed according to treatment, indicating that it was more variable. It was lower in control individuals given no food than in those fed on kelp.

POM has approximately the same ${ }^{13} \mathrm{C}:{ }^{12} \mathrm{C}$ ratio as kelp (Fig. 6), suggesting that it is dominated by kelp derived material. The ${ }^{13} \mathrm{C}:{ }^{12} \mathrm{C}$ ratio of the invertebrates examined is closer to that of kelp and POM than to that of phytoplankton and most of the epiphytic red algae they use as a habitat, suggesting that kelp, in some form, is an important food source. The ${ }^{13} \mathrm{C}:{ }^{12} \mathrm{C}$ value of the red alga Palmaria palmata is however also close to those of both kelp and these species. The ${ }^{15} \mathrm{~N}:{ }^{14} \mathrm{~N}$ ratio was not very different in the invertebrates investigated than in the primary producers, suggesting that many macro-invertebrates occupy a position low in the food web and include algal material in some form in their diet. The variance in their isotope values probably reflects the fact that most of them are omnivorous and include material other than that of algal origin in their diet.
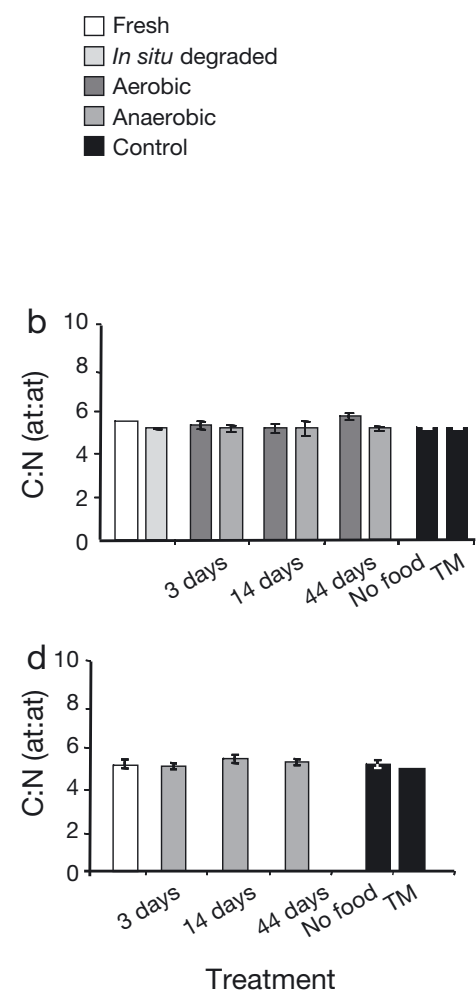
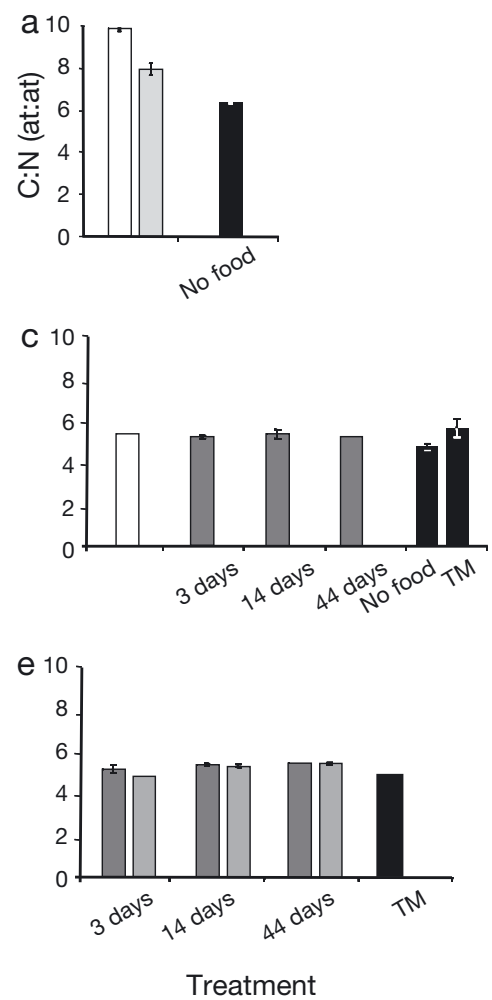

Fig. 5. (a) Rissoa parva; (b) Jassa falcata; (c) Lembos websteri; (d) Ampithoe rubricata; (e) Gammarus locusta. Average $( \pm \mathrm{SE})$ C:N content after feeding experiments. Spaces indicate missing data 


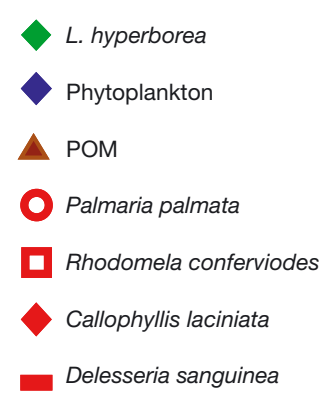

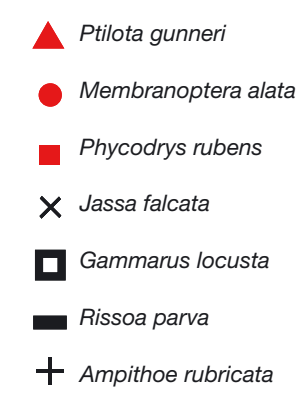

Fig. 6. ${ }^{13} \mathrm{C}:{ }^{12} \mathrm{C}$ and ${ }^{15} \mathrm{~N}:{ }^{14} \mathrm{~N}$ ratio $( \pm \mathrm{SE})$ of kelp (green, $\mathrm{n}=10$ ), phytoplankton (blue, $\mathrm{n}=4$ ), POM (brown, $\mathrm{n}=5$ ) dominating epiphytic red alga (red, $\mathrm{n}=3-6)$, and investigated animal species sampled in situ (black, $\mathrm{n}=1-3$ )

\section{DISCUSSION}

This study has demonstrated that the large primary production in Laminaria hyperborea forests is a potentially important food source for common kelp forest macrofaunal species. It has also demonstrated that this importance depends on bacterial degradation making kelp available as food for common amphipods. Bacterial communities on kelp surfaces thus seem to play a key role in transferring kelp forest primary production to higher levels in the food web. The gastropod Rissoa parva, but none of the investigated amphipod species, was able to live or grow on fresh kelp. The $\mathrm{C}: \mathrm{N}$ ratio was high in R. parva, and more variable than the stable values found in amphipod tissue, suggesting that gastropods may be able to exploit food sources with a higher $\mathrm{C}: \mathrm{N}$ than the crustaceans. This is also reflected in the high resistance to starvation of $R$. parva compared to amphipods. After some time, control R. parva given no food withdrew into their shells, probably to save energy. This behaviour kept them alive for a long time but reduced their body mass noticeably (authors' pers. obs.). Survival of 2 of the 4 amphipod species investigated was lower in individuals fed fresh kelp than in controls given no food. This may have been due to a combination of the negative effect of phlorotannins and the poor nutritional value of fresh kelp, as the $\mathrm{C}: \mathrm{N}$ ratio was nearly 60 . Food C:N ratios lower than 60 have been shown to reduce growth and survival in related species (Poore \& Steinberg 1999, Cruz-Rivera \& Hay 2000b).

Amphipod survival and growth increased with increasing aerobic degradation of the kelp diet. The im-

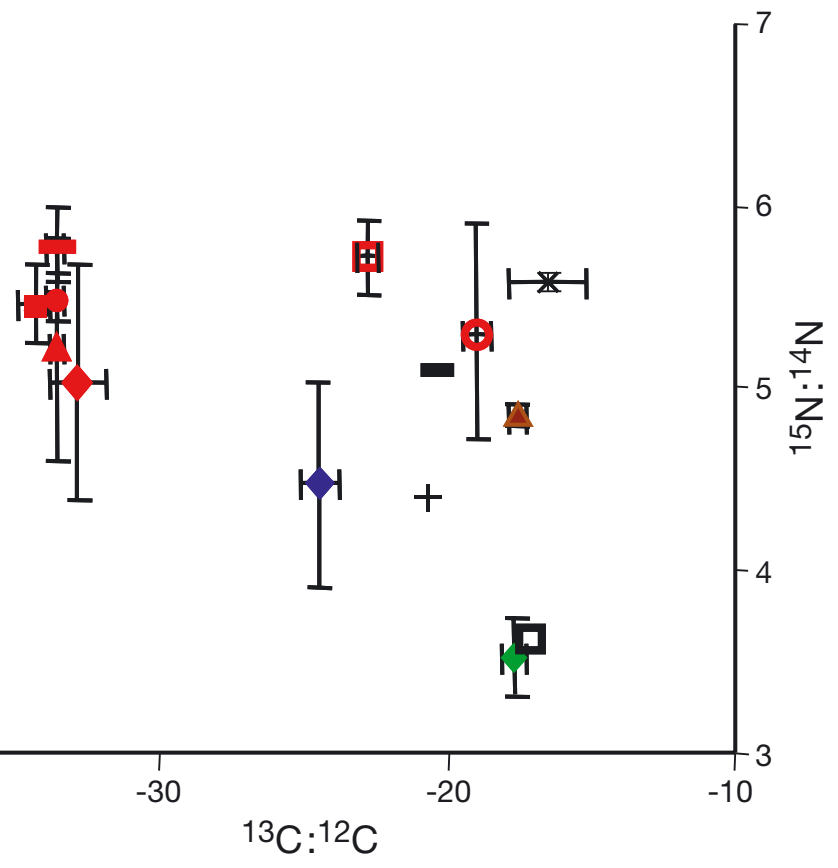

pact of bacterial degradation on kelp was great. The phlorotannin content and the $\mathrm{C}: \mathrm{N}$ ratio decreased quickly when kelp was degraded by bacteria in densities not exceeding those recorded in situ (Armstrong et al. 2000). Survival and growth were lower on all kelp diets than on Tetra $\min ^{\mathrm{TM}}+$ spinach (even though growth rates for closely related species investigated in other studies suggested that this diet is also poor [Cruz-Rivera \& Hay 2000a, H. Christie unpubl. data]). The phlorotannins may have suppressed growth, since the phlorotannin concentration decreased with increasing kelp degradation. Secondary metabolite concentration has previously been reported to be more important than nutritional quality to food suitability (Poore \& Steinberg 1999, Granado \& Caballero 2001). However, the use of diets of lower $\mathrm{C}: \mathrm{N}$ in the above-mentioned studies suggests that the effect of dietary $C: N$ was more critical in our study. Low survival and growth probably also reflected a higher food C:N than the preferred 17 (Russel-Hunter 1970). We expected the amphipods to suffer from $\mathrm{N}$ limitation as a result of the high food $\mathrm{C}: \mathrm{N}$ ratio in their food, and therefore to benefit from processes (or additions to the diet) which decreased this ratio. The stable tissue $\mathrm{C}: \mathrm{N}$ ratio of the amphipods regardless of treatment supports this, implying that $\mathrm{N}$ limitation may have acted as a constraint on $\mathrm{C}$ utilisation, and that either they were not able to compensate successfully for lack of quality by increasing their food intake, or that a higher intake of food increased the deleterious effect of the phlorotannins. However, growth differences decreased in treatments as a function of decreasing $\mathrm{C}: \mathrm{N}$, indicating more successful compensatory feeding when at lower dietary C:N levels. 
The results of the experiments with amphipods suggest that only kelp in an advanced stage of degradation can maintain these animals. The $\mathrm{C}: \mathrm{N}$ ratio and phlorotannin content of the kelp changed little after an initial drop during the first $3 \mathrm{~d}$ of degradation. Nevertheless, survival and growth of Jassa falcata and Gammarus locusta were markedly higher on kelp aerobically degraded for periods longer than $3 \mathrm{~d}$. Anaerobic degradation did not have the same positive effect on animal fitness, although $\mathrm{C}: \mathrm{N}$ and phlorotannin content of the kelp decreased in a similar (but less marked) manner with increasing degradation. These discrepancies may have been related to other food characteristics that were not considered, such as protein (Mattson 1980, Bowen et al. 1995) and water (Pennings et al. 2000) content, which may be important factors. Secondary metabolites such as phlorotannins may render seaweeds unpalatable to consumers before their bioactive metabolites are degraded (Hay 1996). We measured only 'total phlorotannin content', but the molecule size (Boettcher \& Targett 1993) and structural characteristics (Van Altena \& Steinberg 1992) of phlorotannin may modify its effect on consumers, and consumer response to phlorotannins may differ between species (Stern et al. 1996, Ayres et al. 1997, Targett \& Arnold 1998) and populations (Sotka \& Hay 2002). Other processes that take place when kelp is 'aged' have not been considered, but should not be ruled out, as several different processes are expected to occur simultaneously. The reduction in the $\mathrm{C}: \mathrm{N}$ ratio and degradation of phlorotannins are probably 2 important factors.

Although the general trends were the same for the amphipods, i.e. no amphipod could survive on fresh kelp but both survival and growth was better on aerobically degraded kelp, some interspecific differences were found. Adults of the holdfast species Lembos websteri survived better on low-quality food (high $\mathrm{C}: \mathrm{N}$ and phenolic content), and displayed smaller differences in general between treatments than adults of the epiphyte-associated amphipod Jassa falcata. This could indicate that $L$. websteri is a better compensatory feeder than $J$. falcata, perhaps due to its more sedentary behaviour, i.e. the more mobile epiphyte fauna (Norderhaug et al. 2002) require food of higher quality (Cruz-Rivera \& Hay 2000b). Shillaker \& Moore (1987) also found $L$. websteri to have a wide feeding repertoire. The holdfasts function as sediment traps (Moore 1972a, Conradi et al. 1997) that probably accumulate smaller and more degraded particles. If holdfastassociated species are more efficient compensatory feeders, they would be expected to be able to exploit a larger part of the kelp production. Even when better quality detritus (lower $\mathrm{C}: \mathrm{N}$ and phenolic content) is available, they can concurrently utilise food of lower quality than the epiphyte-associated amphipods. The epiphyte-associated fauna are expected to be more dependent on a diet including other constituents, and this may be an important reason for their greater mobility. However, survival differed between the 2 epiphyte-associated amphipods Jassa falcata and Ampithoe rubricata (Fig. 2). The former was negatively affected by fresh kelp, but not the latter. Such differences demonstrate that more data is needed to establish the relationship between the food requirements of the kelp fauna and their ecology.

Laboratory experiments have shown that many crustaceans increase their fitness by high-quality diets or mixed diets (Costa et al. 1996, Cruz-Rivera \& Hay 2000a,b). Such studies, along with multiple-choice feeding experiments (Pavia et al. 1999, Karez et al. 2000), reflect idealised situations. In nature, any individual will be restricted by the food sources available at any one time. Its intake of food items may also be related to factors such as habitat provision or predator refuge (Nicotri 1980, Wakefield \& Murray 1998, Jormalainen et al. 2001). Our results indicate that kelp derived detritus is an important food source for the rich macrofauna of the kelp forest. The ${ }^{15} \mathrm{~N}:{ }^{14} \mathrm{~N}$ isotope data indicate that the species investigated have a low trophic position in the food web (cf. Dunton 2001). The ${ }^{13} \mathrm{C}:{ }^{12} \mathrm{C}$ isotope data suggest that kelp forest POM is mainly kelp derived, and is an important constituent of the diet of these species (cf. Rau et al. 1989), i.e. it is not derived from the majority of the epiphytic red algae upon which these species live. However, fresh kelp and the red alga Palmaria palmata have isotope values similar to POM, and only fresh kelp has been ruled out as a food source in this study. The observed differences in isotope signal between the various macroinvertebrate species also suggest that other food sources are utilised, perhaps in mixed diets. This is common in kelp forest macrofauna and in related species elsewhere (Nair \& Anger 1979a, Shillaker \& Moore 1987, Cruz-Rivera \& Hay 2000b).

\section{CONCLUSIONS}

This study has shown that kelp derived POM with a high C:N ratio is unsuitable as food for many, but not all, consumers until it has gone through an ageing process. It demonstrates the great importance of bacterial degradation in making kelp available as food for the kelp forest consumers and thereby giving them access to a large food source. The results indicate that kelp provides abundant food resources to consumers, and that its large POM production is important to the coastal ecosystem. 
Acknowledgements. This study formed part of a project to investigate the Norwegian kelp forest ecosystem. The project received financial support from the Research Council of Norway. We are grateful to Dr. Mohamed Abdullah for advice on the phlorotannin assays, to Sissel Brubak for assisting us with carrying them out, and to Hartvig Christie for corrections to the manuscript. We are also grateful to Dr. Peter Steinberg and 3 anonymous reviewers for useful suggestions on improving the manuscript. Last, but not least, we are grateful to Anne Lise Bekken for help with feeding the animals.

\section{LITERATURE CITED}

Armstrong E, Rogerson A, Leftley JW (2000) The abundance of heterotrophic protists associated with intertidal seaweeds. Estuar Coast Shelf Sci 50:415-424

Ayres MP, Clausen TP, Maclean SF Jr, Redman AAM, Reichardt PB (1997) Diversity of structure and antiherbivore activity in condensed tannins. Ecology 78:1696-1712

Boettcher AA, Targett NM (1993) Role of polyphenolic molecular size in reduction of assimilation efficiency in Xiphister mocusus. Ecology 74:891-903

Bowen SH, Lutz EV, Ahlgren MO (1995) Dietary protein and energy as determants of food quality: trophic strategies compared. Ecology 76:899-907

Bustamente RH, Branch GM (1996) The dependence of intertidal consumers on kelp-derived organic matter on the west coast of South Africa. J Exp Mar Biol Ecol 196:1-28

Christie H (1995) Description of the kelp forest fauna at Froan, mid Norway; variation in an exposure gradient. Nina Oppdragsmelding 368:1-22

Conradi M, López-González PJ, García-Gómez C (1997) The amphipod community as a bioindicator in Algeciras bay (southern Iberian peninsula) based on a spatio-temporal distribution. Mar Ecol 18:97-111

Corre S, Prieur D, Chamroux S, Floc'h JY, Hourmant A (1989a) Caracterisation des communautés bacteriennes epiphytes de frondes de Laminaria digitata et de debris resultat de leur fragmentation. Cah Biol Mar 30:115-130

Corre S, Prieur D, Chamroux S, Floc'h JY, Hourmant A (1989b) Preliminary study of epiphytic bacterial communities of Laminaria digitata. Can J Microbiol 35:740-743

Costa F, Costa M (1999) Life history of the amphipod Gammarus locusta in the Sado estuary (Portugal). Acta Oecol 20:305-314

Costa FO, Correia AD, Costa MH (1996) Sensitivity of a marine amphipod to non-contaminant variables and to copper in the sediments. Écologie 27:269-276

Cruz-Rivera E, Hay M (2000a) The effect of diet mixing on consumer fitness: macroalgae, epiphytes, and animal matter as food for marine amphipods. Oecologia 123:252-264

Cruz-Rivera E, Hay ME (2000b) Can quantity replace quality? Food choice, compensatory feeding, and fitness of marine mesograzers. Ecology 81:201-219

Cruz-Rivera E, Hay ME (2001) Macroalgal traits and the feeding and fitness of an herbivorous amphipod: the roles of selectivity, mixing and compensation. Mar Ecol Prog Ser 218:249-266

Cummins KW (1974) Structure and function of stream ecosystems. BioScience 24:631-641

Duggins DO, Eckman JE (1997) Is kelp detritus a good food for suspension feeders? Effects of kelp species, age and secondary metabolites. Mar Biol 128:489-495

Duggins DO, Simenstad CA, Estes JA (1989) Magnification of secondary production by kelp detritus in coastal marine ecosystems. Science 245:170-173
Dunton $\mathrm{K}(2001) \delta^{15} \mathrm{~N}$ and $\delta^{13} \mathrm{C}$ measurements of Antarctic peninsula fauna: trophic relationships and assimilation of benthic seaweeds. Am Zool 41:99-112

Fretter V, Manly R (1977) Algal associations of Tricolia pullus, Lacuna vincta and Cerithiopsis tubercularis (Gastropoda) with special reference to the settlement of their larvae. J Mar Biol Assoc UK 57:999-1017

Granado I, Caballero P (2001) Feeding rates of Littorina striata and Osilinus atratus in relation to nutritional quality and chemical defenses of seaweeds. Mar Biol 138:1213-1224

Hagen NT (1983) Destructive grazing of kelp beds by sea urchins in Vestfjorden, northern Norway. Sarsia 68:177-190

Hay ME, Steinberg PD (1992) The chemical ecology of plantherbivore interactions in marine versus terrestrial communities. In: Rosenthal GA, Berenbaum MR (eds) Herbivores: their interactions with secondary plant metabolites. Academic Press, San Diego, p 371-413

Hay ME, Duffy JE, Fenical W, Gustafson K (1988) Chemical defense in the seaweed Dictyopteris delicatula: differential effects against reef fishes and amphipods. Mar Ecol Prog Ser 48:185-192

Hemmi A, Jormalainen V (2002) Nutrient enhancement increases performance of a marine herbivore via quality of its food alga. Ecology 83:1052-1064

Hessen DO (1992) Nutrient element limitation of zooplankton production. Am Nat 140:799-814

Hessen DO, Bjerkeng B (1997) A model approach to planktonic stoichiometry and consumer-resource stability. Freshw Biol 38:447-471

Hessen DO, Sterner RW (1994) Algal nutrient limitation and the nutrition of aquatic herbivores. Annu Rev Ecol Syst 25: $1-29$

Hickman CP, Roberts LS, Larson A (1993) Integrated principles of zoology. Mosby, St. Louis

Jormalainen V, Honkanen T, Heikkilä N (2001) Feeding preferences and performance of a marine isopod on seaweed hosts: cost of habitat specialization. Mar Ecol Prog Ser 220: $219-230$

Kain J (1967) Populations of Laminaria hyperborea at various latitudes. Helgol Wiss Meeresunters 15:489-499

Karez R, Engelbert S, Sommer U (2000) 'Co-consumption' and 'protective coating': two new proposed effects of epiphytes on their macroalgal hosts in mesograzer-epiphytehost-interactions. Mar Ecol Prog Ser 205:85-93

Lawrence JM (1975) On the relationship between marine plants and sea urchins. Oceanogr Mar Biol Annu Rev 13: $213-286$

Mann KH (1982a) Ecology of coastal waters: a system approach. University of California Press, Berkeley

Mann KH (1982b) Kelp, sea urchins and predators: a review of strong interactions in rocky subtidal systems of eastern Canada, 1970-1980. Neth J Sea Res

Mattson WJ (1980) Herbivory in relation to plant nitrogen content. Annu Rev Ecol Syst 11:119-161

Moore PG (1972a) Particulate matter in the sublittoral zone of an exposed coast and its ecological significance with special reference to the fauna inhabiting kelp holdfasts. J Exp Mar Biol Ecol 10:59-80

Moore PG (1972b) The kelp fauna of NE Britain. I. Introduction and the physical environment. J Exp Mar Biol Ecol 13: 97-125

Moore PG (1973) The larger Crustacea associated with holdfasts of kelp (Laminaria hyperborea) in NE Britain. Cah Biol Mar 14:493-518

Nair KCC, Anger K (1979a) Life cycle of Corophium insidiosum (Crustacea, Amphipoda) in laboratory culture. Helgol Wiss Meeresunters 32:279-294 
Nair KKC, Anger K (1979b) Experimental studies on the life cycle of Jassa falcata (Crustacea, Amphipoda). Helgol Wiss Meeresunters 32:444-452

Newell RC, Field JG (1983) The contribution of bacteria and detritus to carbon and nitrogen flow in a benthic community. Mar Biol Lett 4:23-36

Newell RC, Field JG, Griffiths CL (1982) Energy balance and significance of micro-organisms in a kelp bed community. Mar Ecol Prog Ser 8:103-113

Nicotri ME (1977) The impact of crustacean herbivores on cultured seaweed populations. Aquaculture 12:127-136

Nicotri ME (1980) Factors involved in herbivore food preference. J Exp Mar Biol Ecol 42:13-26

Norderhaug KM, Christie H, Rinde E (2002) Colonisation of kelp imitations by epiphyte and holdfast fauna; a study of mobility patterns. Mar Biol 141:965-973

Padilla DK (1985) Structural resistance of algae to herbivores. A biomechanical approach. Mar Biol 90:103-109

Pavia H, Carr H, Åberg P (1999) Habitat and feeding preferences of crustacean mesoherbivores inhabiting the brown seaweed Ascophyllum nodosum (L.) Le Jol. and its epiphyte macroalgae. J Exp Mar Biol Ecol 236:15-32

Pennings SC, Carefoot TH, Zimmer M, Danko SP, Ziegler A (2000) Feeding preferences of supralittoral isopods and amphipods. Can J Zool 78:1918-1929

Poore AGB, Steinberg PD (1999) Preference-performance relationships and effects of host plant choice in an herbivorous marine amphipod. Ecol Monogr 69:443-464

Rau GH, Mearns AJ, Young DR, Olson RJ, Schafer HA, Kaplan IR (1983) Animal ${ }^{13} \mathrm{C} /{ }^{12} \mathrm{C}$ correlates with trophic level in pelagic food webs. Ecology 64:1314-1318

Rau GH, Heyraud M, Cherry RD $(1989){ }^{15} \mathrm{~N} /{ }^{14} \mathrm{~N}$ and ${ }^{13} \mathrm{C} /{ }^{12} \mathrm{C}$ in mesopelagic shrimp from the northeast Atlantic Ocean: evidence for difference in diet. Deep-Sea Res 36:1103-1110

Russel-Hunter WD (1970) Aquatic productivity. Macmillian, New York

Schultze K, Janke K, Krüß A, Weidemann W (1990) The macrofauna and macroflora associated with Laminaria digitata and L. hyperborea at the island of Helgoland (German Bight, North Sea). Helgol Wiss Meeresunters 44:39-51

Seiderer LJ, Newell RC (1985) Relative significance of phytoplankton, bacteria and plant detritus as carbon and nitrogen resources for the kelp bed filter-feeder Choromytilus meridionalis. Mar Ecol Prog Ser 22:127-139

Shillaker RO, Moore PG (1987) The feeding habits of the amphipods Lembos websteri Bate and Corophium bonellii Milne Edwards. J Exp Mar Biol Ecol 110:93-112

Sjøtun K, Fredriksen S, Rueness J, Lein TE (1995) Ecological

Editorial responsibility: Otto Kinne (Editor),

Oldendorf/Luhe, Germany studies of the kelp Laminaria hyperborea (Gunnerus) Foslie in Norway. In: Skjoldal HR, Hopkins C, Erikstad KE, Leinaas HP (eds) Ecology of fjords and coastal waters. Elsevier Science, Amsterdam, p 525-536

Sjøtun K, Fredriksen S, Rueness J (1996) Seasonal growth and carbon and nitrogen content in canopy and first-year plants of Laminaria hyperborea (Laminariales, Phaeophyceae). Phycologia 35:1-8

Sotka EE, Hay ME (2002) Geographic variation among herbivore populations in tolerance for a chemically rich seaweed. Ecology 83:2721-2735

Steneck RS, Watling L (1982) Feeding capabilities and limitations of herbivorous molluscs: a functional approach. Mar Biol 68:299-312

Stern JL, Hagermann AE, Steinberg PD, Mason PK (1996) Phlorotannin-protein interactions. J Chem Ecol 22: 1877-1899

Targett NM, Arnold TM (1998) Predicting the effects of brown algal phlorotannins on marine herbivores in tropical and temperate oceans. J Phycol 34:195-205

Taylor RB, Sotka E, Hay ME (2002) Tissue-specific induction of herbivore resistance: seaweed response to amphipod grazing. Oecologia 132:68-76

Thrush SF (1986) The sublittoral macrobenthic community structure of an Irish sea-lough: effect of decomposing accumulations of seaweed. J Exp Mar Biol Ecol 96: 199-212

Toth GB, Pavia H (2002a) Intraplant habitat and feeding preference of two gastropod herbivores inhabiting the kelp Laminaria hyperborea. J Mar Biol Assoc UK 82:243-247

Toth GB, Pavia H (2002b) Lack of phlorotannin induction in the kelp Laminaria hyperborea in response to grazing by two gastropod herbivores. Mar Biol 140:403-409

Van Alstyne KL (1995) Comparison of three methods for quantifying brown algal polyphenolic compounds. J Chem Ecol 21:45-58

Van Altena IA, Steinberg PD (1992) Are differences in the response between North American and Australasian marine herbivores to phlorotannins due to differences in phlorotannin structure? Biochem Syst Ecol 20:493-499

Vetter EW (1995) Detritus-based patches of high secondary production in the nearshore benthos. Mar Ecol Prog Ser 120:251-262

Wakefield RL, Murray SN (1998) Factors influencing food choice by the seaweed-eating marine snail Norrisia norrisi (Trochidae). Mar Biol 130:631-642

Warén A (1996) Ecology and systematics of the North European species of Rissoa and Pussilina (Prosobranchia: Rissoidae). J Mar Biol Assoc UK 76:1013-1059

Submitted: July 5, 2002; Accepted: February 11, 2003

Proofs received from author(s): May 22, 2003 